
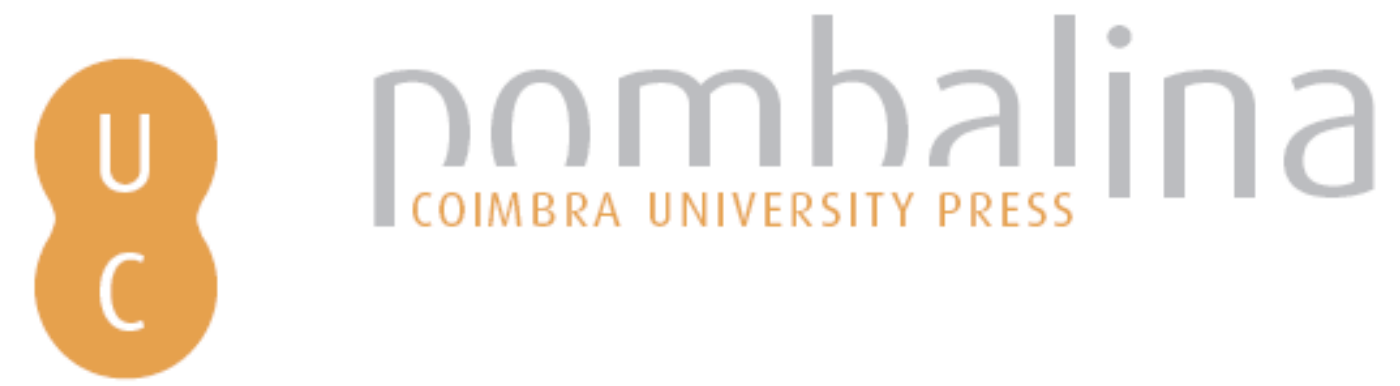

Theoretical approaches for evaluating the economic efficiency of the aerial firefighting helping strategic planning

Autor(es): Restas, Agoston

Publicado por: Imprensa da Universidade de Coimbra

URL

persistente: URI:http://hdl.handle.net/10316.2/34019

DOI: DOI:http://dx.doi.org/10.14195/978-989-26-0884-6_212

Accessed : $\quad$ 26-Apr-2023 13:05:29

A navegação consulta e descarregamento dos títulos inseridos nas Bibliotecas Digitais UC Digitalis, UC Pombalina e UC Impactum, pressupõem a aceitação plena e sem reservas dos Termos e Condições de Uso destas Bibliotecas Digitais, disponíveis em https://digitalis.uc.pt/pt-pt/termos.

Conforme exposto nos referidos Termos e Condições de Uso, o descarregamento de títulos de acesso restrito requer uma licença válida de autorização devendo o utilizador aceder ao(s) documento(s) a partir de um endereço de IP da instituição detentora da supramencionada licença.

Ao utilizador é apenas permitido o descarregamento para uso pessoal, pelo que o emprego do(s) título(s) descarregado(s) para outro fim, designadamente comercial, carece de autorização do respetivo autor ou editor da obra.

Na medida em que todas as obras da UC Digitalis se encontram protegidas pelo Código do Direito de Autor e Direitos Conexos e demais legislação aplicável, toda a cópia, parcial ou total, deste documento, nos casos em que é legalmente admitida, deverá conter ou fazer-se acompanhar por este aviso.

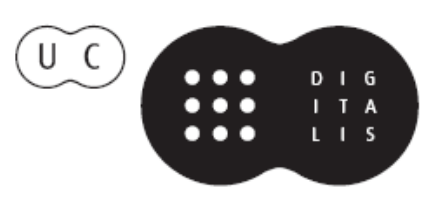




\section{ADVANCES IN}

Forest Fire

\section{RESEARCH}

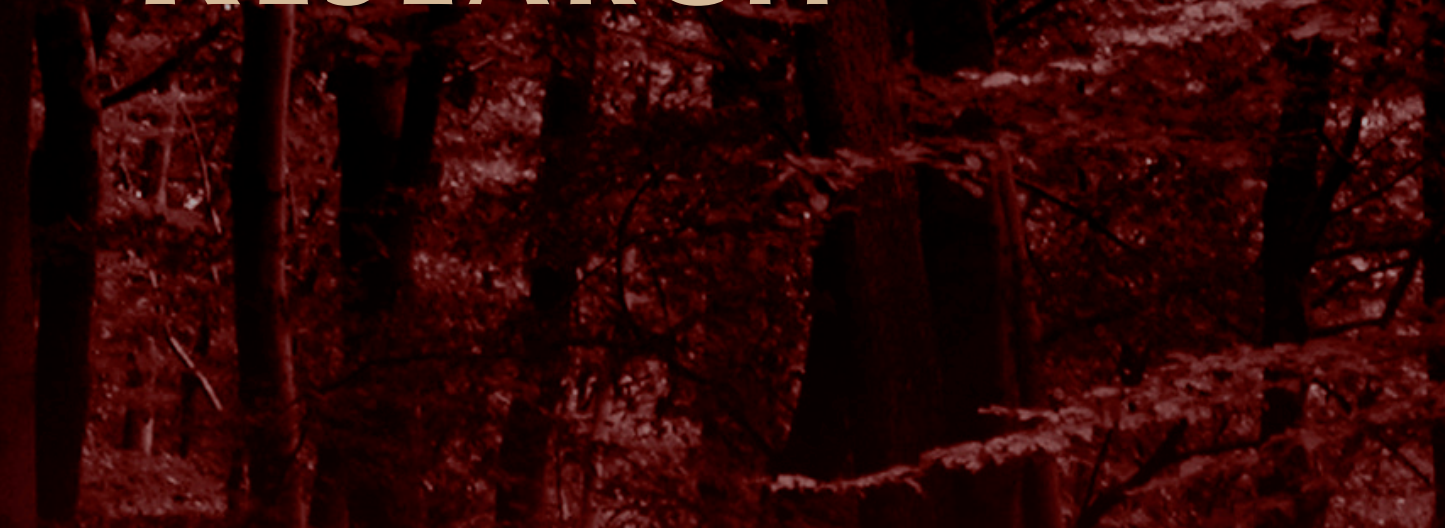

\section{DOMINGOS XAVIER VIEGAS}

\section{EDITOR}




\title{
Theoretical approaches for evaluating the economic efficiency of the aerial firefighting helping strategic planning
}

\author{
Agoston Restas \\ National University of Public Service, Budapest, Hungary, Restas.Agoston@uni-nke.hu
}

\begin{abstract}
Introduction: Aerial firefighting is very expensive solution; therefore it isn't useless to study it by the criteria of efficiency. But the meaning of efficiency for fire managers can be different from the meaning of efficiency for economists. Economic efficiency is stricter than technical efficiency. Method: this research created and used rectangular and concentric circles models, than made transport analysis and rate calculation. Results and discussion: The rectangular model shows the criteria of economic efficiency of aerial firefighting. The results from rectangular model can be transferred also to the concentric circles model. Based on the concentric circle model we can define both the economic efficiency of aerial firefighting and minimal criteria of successful suppression expressed by the elementary information we have regarding the actual fire. This paper points also at some principle mistakes often made by marketing to overrate the advantages of some aerial products, agents or procedures. Even if it is very difficult to take into consideration all circumstances and assumptions which are found during firefighting process but there are some theories that can help us to assess the economical effectiveness of aerial product, agent or procedure more precisely than rated nowadays by the marketing.
\end{abstract}

Keywords: aerial firefighting, economic efficiency, rectangular model, concentric circle model, transport analysis

\section{Introduction}

In this article author makes a difference between the professional and economical effectiveness that is efficiency. Efficiency is obviously stronger phenomena, in this case not just the professional effectiveness but the criteria of the efficiency must be satisfied. No doubt in the sphere of state protection (police, medical service, disaster management, fire service) it is very difficult to speak about efficiency, much easier about the political or social effectiveness. However author is sure there are ways to find the balance between useful actions and costs. Aerial firefighting is a very expensive extinguishing method; therefore it is not useless to look through some of its economic aspects.

Firstly, author makes two models, which are rectangular and concentric circle model, to make it easier to understand some features of the economic aspects of firefighting. Naturally, the assumptions in both models are idealistic, meaning that they require more development. After models, author focuses on extinguisher materials such as pure water, foam and retardant and gives some different aspects of their effectiveness than usual.

\section{Rectangular model}

First model examine a forested area limited by rectangular without concrete geometric data. Assumptions are idealistic, like homogenous forest, flat area; there is no wind, etc. In this model the fire front spreads linearly (Figure 1.). Author demonstrates this theory by more rectangular, placing them next to each other, which shows the fire development by geometric. Some part of this model is similar to the model used by Australian experts however not the same (Gould at al., 2009).

After starting the suppression (B) the controlled line takes „ $\alpha$ ” with the frame of this example edge (C). During the suppression this controlled line will continue till the opposite edge of the frame, meaning that the fire front is extinguished (D). Based on Pythagoras theory it is easy to understand 
that the value of , $\alpha$ " depends on the speed of fire $\operatorname{spread}\left(\mathrm{v}_{\text {fire }}\right)$ and the speed of suppression ( $\left.\mathrm{v}_{\text {suppression }}\right)$. The higher the speed of suppression related to speed of fire spread (R), the higher the angle „ $\alpha$ ” is and vice versa.

$$
R\left(\frac{v_{\text {fire }}}{v_{\text {sup pression }}}\right) \uparrow \downarrow \Rightarrow \alpha \uparrow \downarrow
$$

Before the fire front forested area can be saved ( $\left.\mathrm{M}_{\text {forest }}\right)$, beyond it can be count as damages ( $\left.\mathrm{K}_{\text {forest }}\right)$. The main purpose of the suppression is that the value of saved forest be as high as possible or the damages be as low as possible. Author means, we search the end values of the positive options.

$$
M_{\text {forest }} \Rightarrow \max \text {; illetve } K_{\text {forest }} \Rightarrow \min
$$

Above statement can be accepted by the view of professional but since it doesn't count with the cost of extinguishing the result can't be the standard for the view of national economy.

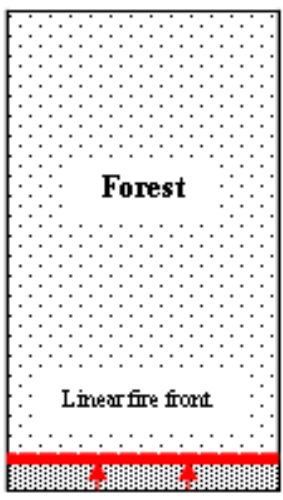

A

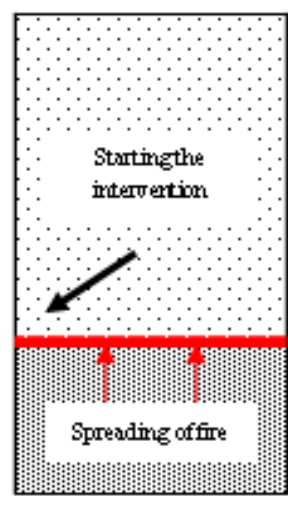

B

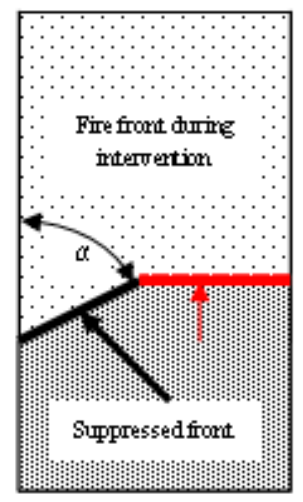

$\mathrm{C}$

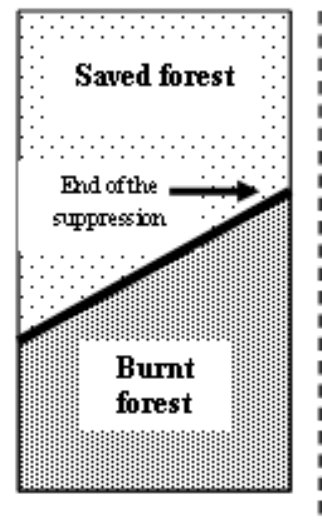

$\mathrm{D}$

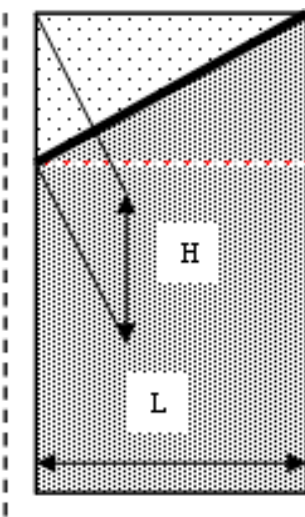

$\mathrm{E}$

Figure 1. Rectangular model

To maximize the end value of the professional effectiveness' function can't be justify in all cases at the view of national economy. At the latest one all costs of resources must be counted, such as technical and human resources but even the in-material value of the forest and the higher risk of citizens caused by absence of firefighters from urban area.

If the cost of suppression is higher than the saved forest the action is uneconomical in view of national economy. Looking at the rectangular model the efficiency of national economy is valid till the saved forest is higher than the cost of suppression.

$$
M_{\text {forest }} \geq \Sigma C_{A F F} \Rightarrow \gamma_{N E} \geq 1
$$

$\mathrm{M}_{\text {forest }}$ - value of the saved forest [€]

$\mathrm{C}_{\mathrm{AFF}}-$ cost of aerial suppression $[€]$

$\gamma_{\mathrm{NE}} \quad-$ efficiency of the national economy [-]

Using the notation of the rectangular model the first part of formula (2.3) can be expressed also in another way.

$$
\frac{1}{2} L H P_{\text {forest }} \geq \Sigma C_{A F F}
$$


$\mathrm{L} \quad-$ width of the forest area [m]

$\mathrm{H} \quad-$ fire spread from the beginning of the suppression till the end of it [m]

$\mathrm{P}_{\text {forest }}-$ unit value of the forest $\left[€ \mathrm{~m}^{-2}\right]$

This model doesn't count with the burnt area at the beginning of the suppression, not during the action or at the end of it. In this case the efficiency of the suppression in view of national economy doesn't depend directly on the burnt area.

Triangles with „L” width fire front, , $\alpha$ ” angles and „H” length in this model are same in any time of beginning the suppression and also same the costs belonged to these triangles.

Based on the rectangular model we get the threshold limit in that case, if the cost of aerial firefighting is equal to the value of the saved forest. In cases of later beginning of the suppression, the cost of aerial firefighting remains the same however the value of the saved forest is reducing continuously till that where remains only the „L- $\alpha-\mathrm{H}$ ” featured triangle (E). It means the threshold limit of the efficiency geometrically.

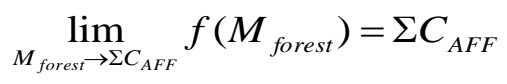

In this case, if both the above threshold limit is realized and the efficiency of the aerial firefighting is valid, in any earlier beginning time of the suppression will satisfy the requirements of the efficiency too. The earlier is the beginning of the suppression, the higher the value of the saved forest is. The limit value gives just the minimum threshold of satisfying the criteria of the efficiency.

The angle , $\alpha$ " of the suppressed fire front depends on the rate of fire spread and the speed of aerial firefighting. Higher fire spread causes lower angle „, $\alpha$ " and longer time of suppression and vice versa. In view of higher efficiency the higher angle „ $\alpha ”$ is required.

\section{Concentric circles model}

The rectangular model counts with linear fire front however in the reality almost each fire starts from small ignition points. In case of ideal and positive spread conditions the fire front will spread radially.

\subsection{Necessary but not yet sufficient condition for the efficient suppression}

Model counts with small ignition point, „Vfire” speed of fire spread, „t $\mathrm{t}_{\text {freely }}$ " time of freely fire spread, but other conditions are ignored. In this case the burnt area „A fire” (Figure 2: $A_{t 1}-A_{t 3}$ ) can be given with the next formula:

$$
A_{\text {fire }}=\left(v_{\text {fire }} t_{\text {freely }}\right)^{2} \Pi
$$

Following time units (sec, min, hour) burnt areas form concentric circles. This model got its name of these circles. Distance between the circles depends on the rate of fire spread. The „K $\mathrm{K}_{\text {front }}$ fire front can be given by the formula (3.2) and the changing of it is by the formula (3.3).

$$
K_{\text {front }}=2 \Pi v_{\text {fire }} t_{\text {freely }} \quad \text { (3.2) } \quad \Delta K_{\text {front }}=2 \Delta t v_{\text {fire }} \Pi
$$

In the formula (3.3) the extent of the , $\Delta \mathrm{R}$ " radiation change can be given by the formula (3.4).

$$
\Delta R=v_{\text {fire }} \Delta t
$$


The effectiveness of the suppression can be demonstrated by the length of the suppressed fire section per the time units, that is, the speed of fire front suppression.

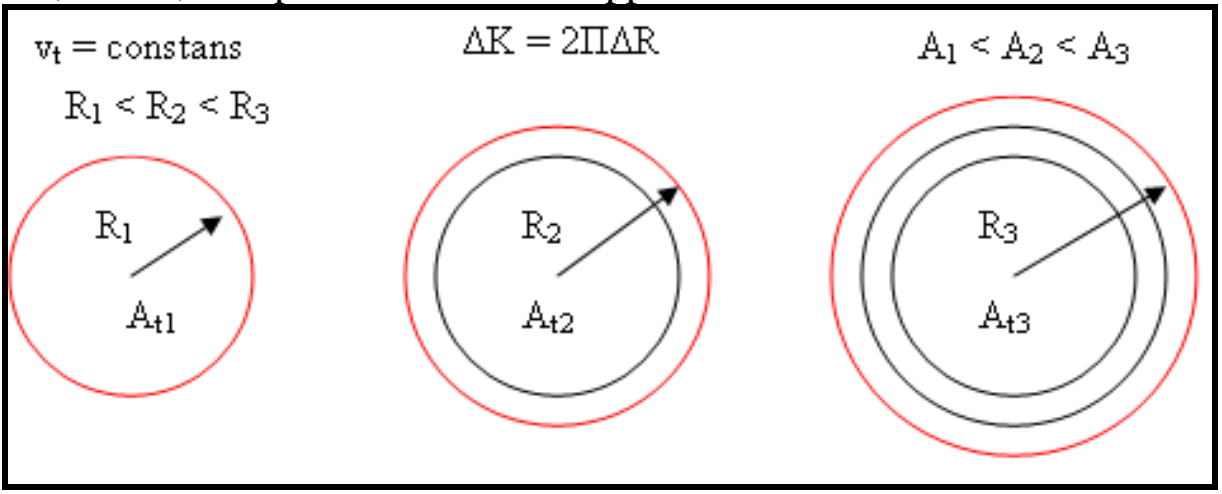

Figure 2. Concentric circles model

Based on the above for demonstrating the capability of the aerial means suppressing fire front author introduce the term of speed of aerial firefighting (,VAFF"). It means the length of the fire front suppressed by aircrafts.

$$
v_{A F F}=\frac{L_{\text {suppression }}}{t_{\text {suppression }}}
$$

- $\quad \mathrm{VAFF}_{\mathrm{AFF}}-$ speed of aerial firefighting $\left[\mathrm{ms}^{-1}\right.$; practically it can be $\mathrm{mmin}^{-1}$ or $\left.\mathrm{mhour}^{-1}\right]$;

- $\quad \mathrm{L}_{\text {suppression }}$ - length of the suppressed fire front [m];

- $\quad t_{\text {suppression }}$ - time for suppression [s; practically min, or hour].

To extinguish the fire successfully, the condition must be met that the interveners suppress fire spread. The firefighters have to extinguish the fire front, whose growth per unit of time is equal to the change in perimeter based on the concentric circles model. Thus, the success and effectiveness of the firefighters' work should not be related directly to the speed of fire spread but rather to the change in perimeter! At the beginning of extinguishment, the speed of the extinguishment of fire front, in this case the speed of aerial firefighting must reach and later exceed the speed of the change of the fire front, that is, the change of the fire front within a given unit of time.

$$
L_{\text {suppression }}>\Delta K_{\text {front }}
$$

Using the formula (3.6) to extinguish successfully, the next criteria must be satisfied:

$$
v_{A F F}>\frac{\Delta K_{\text {front }}}{t_{\text {suppression }}}, \text { or in other form: } v_{A F F} t_{\text {suppression }}>\Delta K_{\text {front }}
$$

By ordering the above, it becomes clear that in practice the initial condition can be calculated in a simplified way, where we need to take the speed of fire spread multiplied by $2 \Pi$.

$$
v_{A F F}>2 \Pi v_{\text {fire }}
$$

Above in-equality is necessary but not yet sufficient condition for the efficiency of the national economy. Based on mathematical formulas and the logical deductions regarding the concentric circles model author made the following statements: 
1. If the speed of extinguishing the fire front - in this case the speed of the aerial firefighting - is below the speed of changing the fire front, the aerials are unable to extinguish the fire (initial attack).

2. If the speeds above are identical, the length of fire front will remain but the burnt area will extend (beginning situation; later the balance follow 2Пrad).

3. If the speed of extinguishing made by aerials is higher than the increase of the fire front, fire can be suppressed.

Based on the above logical flow we can define both the economic efficiency of aerial firefighting and minimal criteria of successful suppression expressed by the elementary information we have regarding the actual fire. Naturally, the above statements are valid only at the time of beginning the suppression. Later, it modifies as changing the angle of suppressed fire front by the rules of $2 \Pi \mathrm{rad}$.

\subsection{Sufficient condition for the efficient suppression}

In the examination of the rectangular model, the conditions of efficient extinguishment in terms of the national economy have already been recorded. Based on them, the extinguishment can be regarded efficient if the amount of the saved value reaches the total costs of the extinguishment. Then, the condition of efficiency is met satisfactorily (2.3). It applies to both the rectangular and the concentric circles model.

One feature of extinguishing forest fires is that regardless of the size of the forest burning, we tend to concentrate on the extinguishment of the fire front, which can be regarded as straight fire line suppression. It can be done or it can be accepted because in case of long-lasting uncontrolled fire spread, the curve of the fire front is hardly perceptible, in practice it can be ignored, so it's linear. If we concentrate on a very small section of fire front, the conclusions of the rectangular model can be applied here, too!

Provided we accept the above statements - the adaptation of the limit values of efficiency set in the rectangular model (2.4) to the very small section of the concentric circles model (3.7) - the formula can be created in the following way:

$$
\frac{1}{2} L H p_{\text {forest }} \geq \Sigma C_{A F F} \Rightarrow \frac{1}{2} \Delta K v_{\text {fire }} t_{\text {sup pression }} p_{\text {forest }} \geq \Sigma C_{A F F}
$$

Moreover, the limit value of the efficiency criterion of aerial firefighting out of formula (3.8):

$$
2 \Pi v_{\text {fire }}=v_{A F F}
$$

By reversing the equation and substituting the form pertaining to the actual time of formula (3.3):

$$
C_{A F F}^{f l y} t_{\text {sup pression }} \leq \frac{1}{2} 2 \Pi v_{\text {fire }} t_{\text {sup pression }} v_{\text {fire }} t_{\text {sup pression }} p_{\text {forest }}
$$

$$
\begin{aligned}
& \mathrm{C}_{\mathrm{AFF}}^{\mathrm{fly}}-\text { unit costs of aerial firefighting }\left[€ \mathrm{~h}^{-1} ; € \mathrm{~min}^{-1}\right] \\
& \qquad C_{A F F}^{f l y} t_{\text {sup pression }} \leq \frac{1}{2} 2 \Pi\left(\frac{v_{A F F}}{2 \Pi}\right)^{2} t_{\text {suppression }}^{2} p_{\text {forest }}
\end{aligned}
$$

Ordering the above formulas and interpret it to a unit time, that is $t_{\text {suppression }}=1 \mathrm{~min}$, we can get for the speed of the aerial firefighting the distance of suppression per a minute, that is $v_{A F F}=l_{A F F} 1 \mathrm{~min}^{-1}$.

$$
l_{A F F} \geq \sqrt{\frac{4 \Pi C_{A F F}^{f l y}}{p_{\text {forest }}}}
$$


Based on the above formula we can see that some data are enough for the statement of efficient suppression in view of national economy: as the length of suppressed fire front per unit $\left(1_{\mathrm{AFF}}\right)$, the unit cost of aerial firefighting $\left(\mathrm{C}_{\mathrm{AFF}}{ }^{\text {fly }}\right)$ and the unit costs of forest ( $\left.\mathrm{p}_{\text {forest }}\right)$. Remake the formula and apply it to speed of fire spread:

$$
C_{A F F}^{f l y} \leq \prod p_{\text {forest }} v_{\text {fire }}^{2}
$$

It has to take into account that the above values are limit values; satisfying them aerial firefighting will satisfy the criteria of efficiency in view of national economy too.

\section{Investigating extinguisher materials}

\subsection{Extinguishing material is water - using external bucket for bombing}

The most common and simplest extinguisher material is water. Using water we count actually only the cost of logistics that is aerial means. In this case the cost of unit water is a quotient of the aircraft cost and water capacity. It can be expressed by the next formula:

$$
C_{W}=\frac{C_{A}}{V_{W}}
$$

- $\mathrm{C}_{\mathrm{W}}=$ cost of water capacity $\left[€ \mathrm{~kg}^{-1}\right]$;

- $\mathrm{C}_{\mathrm{A}}=$ cost of aircraft per hour $\left[€ \mathrm{~h}^{-1}\right]$;

- $\quad \mathrm{V}_{\mathrm{W}}=$ volume of water capacity per hour $\left[\mathrm{kgh}^{-1}\right]$;

- For example, in this article $\mathrm{C}_{\mathrm{W}}=0.3 € \mathrm{~kg}^{-1}$

Water, as the most common and simplest extinguisher material, can be taken to the others as a reference regarding extinguishing effects. Therefore author introduce the term of water equivalent per unit of any extinguishing material regarding extinguishing effects $\left(\mathrm{C}_{\mathrm{x}=\mathrm{W}}\right)$. Naturally, water has its own water equivalent that is cooling effect caused by the specific heat capacity. Moreover not just the extinguishing effects of water but also the cost of water equivalent can be taken as a reference $\left(\mathrm{C}_{\mathrm{W}}=\mathrm{C}_{\mathrm{W}=\mathrm{W}}\right)$. Since the water has its own water equivalent, in the above case it is not important to discuss it. However, later, it gets an important role and as a starting point of a series it belongs logically to water.

Buckets can have significant losses of carried volume during the action, some observer estimate it more than $50 \%$ (Jambrik, 2007; Imreh at al., 2009). Since the losses usually taken with high rate, in this examples author can't ignore it, on average he counts with $25 \%$. Because of the high rate of losses, we have to take into account not the bucket capacity but the part of it which is dropped to fire front. Consequently, in view of efficiency we have to share the cost of transportation (aerial firefighting) with a reduced volume of the bucket capacity (effective part), resulting higher cost per effective unit water. It can be expressed by the next formula:

$$
C_{W_{-} e f f}=\frac{C_{W}}{\gamma_{B}}
$$

- $\quad \mathrm{C}_{\mathrm{W} \_ \text {eff }}=$ cost of unit water dropped to fire front $\left[€ \mathrm{~kg}^{-1}\right]$;

- $\gamma_{\mathrm{B}}=$ coefficient of the bucket effectivity [];

- For example, in this article, in case of $\gamma_{\mathrm{B}}=0.75, \mathrm{C}_{\mathrm{W} \_ \text {eff }}=0.4 € \mathrm{~kg}^{-1}$

Based on the above the effectiveness can be expressed by the next statement: the extinguishing capacity of $1 \mathrm{~kg}$,water” at the beginning of the transportation (taking off) expressed by water 
equivalent is equal to its own volume, it costs $0.3 € \mathrm{~kg}^{-1}$, regarding the effective part of the capacity at the end of the transportation (dropping to fire front) is $0.4 € \mathrm{~kg}^{-1}$.

\subsection{Extinguishing material is foam - using internal tank}

In this case the cost of foam concentrate multiplied with the mixing rate has to be added to the quotient of the aircraft cost and water capacity. It can be expressed by the next formula:

$$
C_{F}=\frac{C_{A}}{V_{W}}+C_{C} R_{\text {mix }}
$$

- $\quad \mathrm{C}_{\mathrm{F}}=$ cost of foam solution capacity $\left[€ \mathrm{~kg}^{-1}\right]$;

- $\mathrm{C}_{\mathrm{C}}=$ cost of foam concentrate $\left[€ \mathrm{~kg}^{-1}\right]$;

- $\quad \mathrm{R}_{\text {mix }}=$ rate of mix [\%];

- For example, in this article, in case of $\mathrm{C}_{\mathrm{C}} \mathrm{R}_{\text {mix }}=0.1 € \mathrm{~kg}^{-1}, \mathrm{C}_{\mathrm{F}}=0.4 € \mathrm{~kg}^{-1}$

Author's experiment shows that beside the cooling effect of foam, caused by the specific heat capacity of the water content, it also has an extra extinguishing effect caused by the structure of the foam that is isolation effect (Restas, 2012). This extra effect delays the ignition of the surface over time than reasonable just by the water content of the foam. This delay, as an extra extinguishing effect, can be expressed by water equivalent. It means, how much water quantity could equal the same delay that is caused by the structure of the foam.

In case of foam author found that it is twice more effective than water (Restas, 2012) however other experts state it 3 times more (Theo, 2009); it generates a coefficient of foam equivalent to water effect. Author insists on his own data; it means $1 \mathrm{~kg}$ foam has as much extinguishing effect as $2 \mathrm{~kg}$ water (cooling effect) has. In case of cost of extinguishing effect of foam the coefficient also has to be taken into account. It can be expressed by the next formula:

$$
C_{F=W}=\frac{C_{F}}{Y_{\text {exp }}}
$$

- $\quad \mathrm{C}_{\mathrm{F}=\mathrm{W}}=$ cost of foam solution capacity equivalent to water effect $\left[€ \mathrm{~kg}^{-1}\right]$;

- $\quad Y_{\exp }=$ coefficient of foam solution equivalent to water effect [];

- For example, in this article, in case of $\mathrm{Y}_{\mathrm{exp}}=2, \mathrm{C}_{\mathrm{F}=\mathrm{W}}=0.2 € \mathrm{~kg}^{-1}$

Obviously the on-board installed tank has less transport losses than buckets, many times it is ignored. Author takes into account the losses of on-board tank about $10 \%$; it means the coefficient of the effectiveness is 0.9. The cost of the effective part of the foam solution dropped from the tank expressed by water equivalent can be given by the next formula:

$$
C_{F=W_{-} e f f}=\frac{C_{F=W}}{\gamma_{T}}
$$

- $\quad \mathrm{C}_{\mathrm{F}=\mathrm{W}_{-} \text {eff }}=$ cost of useful part of foam solution capacity equivalent to water effect [€ $\left[\mathrm{kg}^{-}\right.$ ${ }^{1}$ ];

- $\quad \gamma_{\mathrm{T}}=$ coefficient of on-board tank effectivity [];

- For example, in this article, in case of $\gamma_{\mathrm{T}}=0.9, \mathrm{C}_{\mathrm{F}=\mathrm{W}_{-} \text {eff }}=0.22 \mathrm{€kg}^{-1}$ 
Based on the above the effectiveness can be expressed by the next statement: the extinguishing capacity of $1 \mathrm{~kg}$,foam solution” at the beginning of the transportation (taking off) expressed by water equivalent is equal to $2 \mathrm{~kg}$, it costs $0.4 € \mathrm{~kg}^{-1}$, regarding the effective part of the capacity at the end of the transportation (foam on surface) is $0.22 \mathrm{Ekg}^{-1}$.

\subsection{Results and discussion regarding foam applications}

Based on the results of the practical example, we can deduct that failing to use foams is a professional mistake - if we presume the effectiveness of one unit is twice as much. Yet there is no practical evidence of frequent application of foams. Obviously, it might have numerous reasons. One of them must be the additional cost. It is a mistake to compare the extra cost of foam as an extinguisher to that of water. As water costs practically nothing, regardless of how cheap the foam concentrate is, it would be still significant compared to water. The mistake lies in comparing the costs of the extinguishers or those of the technical equipment (amortisation) instead of comparing the total costs of different extinguishing methods, including the operation cost of the aircraft. The latter one cannot be separated, since it represents a considerable amount within the total cost.

In the above example the difference between the cost of $1 \mathrm{~kg}$ water and $1 \mathrm{~kg}$ foam solution is very drastic $\left(0 € \mathrm{~kg}^{-1}=>0.1 € \mathrm{~kg}^{-1}\right)$, but taking into account the cost of transportation (aircrafts) the difference is moderate $\left(0.3 € \mathrm{~kg}^{-1}=>0.4 € \mathrm{~kg}^{-1}\right)$, it means only $33 \%$ ! If the effectiveness of the unit foam solution in water equivalent rise also just with $33 \%$, it means, economic point of view there is no difference between the extinguishers. However, the coefficient of the effectiveness of the foam solution in water equivalent is 2 , which means the effectiveness rose $100 \%$ !

We have to look for another excuse for failing to use it. In the author's opinion three basic things can hinder the application of foam concentrates.

1. Logistics: The application of foam concentrates requires logistics support. Water is freely available and the loading of aircrafts can be carried out without any external help, so this is the simplest method.

2. Tactics: In aerial firefighting the fire front is directly attacked with water, while in the case of foams the protection strip is targeted primarily.

3. Psychology: The additional related costs the need for logistics support and the difficulties in the application of foams may generate negative prejudices without any professionally valid researches.

Based on the above, in the example, the cost doesn't rise by $33 \%$ but in water equivalent reduces by $45 \%\left(0.4 € \mathrm{~kg}^{-1}=>0.22 € \mathrm{~kg}^{-1}\right)$ !

\subsection{Extinguishing material is retardant - using internal tank}

In case of retardant the method is similar to the foam concentrate. The cost of retardant multiplied with the mixing rate has to be added to the quotient of the aircraft cost and water capacity. It can be expressed by the next formula:

$$
C_{R}=\frac{C_{A}}{V_{W}}+C_{r e t} R_{m i x}
$$

- $\mathrm{C}_{\mathrm{R}} \quad=$ cost of retardant capacity $\left[€ \mathrm{~kg}^{-1}\right]$;

- $\mathrm{C}_{\text {ret }}=$ cost of retardant $\left[€ \mathrm{~kg}^{-1}\right]$;

- $\mathrm{R}_{\text {mix }}=$ rate of $\operatorname{mix}[\%]$. 
Retardant also has an extra extinguishing effect, therefore the effectiveness in water equivalent similar to foam solution - have to be counted with coefficient too. It can be expressed by the next formula:

$$
C_{R=W}=\frac{C_{R}}{Y_{R}}
$$

- $\quad \mathrm{C}_{\mathrm{R}=\mathrm{W}}=$ cost of retardant capacity equivalent to water effect $\left[€ \mathrm{~kg}^{-1}\right]$;

- $\quad Y_{R}=$ coefficient of retardant equivalent to water effect [].

The cost of the effective part of the retardant dropped from the tank expressed by water equivalent can be given by the next formula:

$$
C_{R=W_{-} e f f}=\frac{C_{R=W}}{\gamma_{T}}
$$

- $\quad \mathrm{C}_{\mathrm{R}=\mathrm{W} \_ \text {eff }}=$ cost of useful part of retardant capacity equivalent to water effect $\left[€ \mathrm{~kg}^{-1}\right]$;

- $\gamma_{\mathrm{T}}=$ coefficient of on-board tank effectivity [].

The extinguishing effect of the foam based on water equivalent was determined by tests R-20F (Restas, 2012) and R-10A (Restas, 2014). However, tests targeting the effectiveness of retardants have not been conducted yet so the author has not found any acceptable values to be compared in the specialist literature. Thus, to make practical calculations, I applied logical deductions, expert estimations and hypothesis analysis.

\subsection{Results and discussion regarding retardant applications}

$\mathrm{n}$ the test, the basic conditions are the same as the previous ones. The effectiveness of the retardants is definitely higher than that of water. To determine it, the author makes the following logical deduction:

1. The author accepts that retardants are able to provide protection against crown fire, that is, against fire intensity of $8.000 \mathrm{kWm}^{-1}$;

2. Nobody implies - and there is no practical evidence - that retardants are able to withstand any fire intensity. Its extinguishing effect is obviously lower than the one which is able to suppress extreme fire of $18.000 \mathrm{kWm}^{-1}$ intensity;

3. Based on the author's logical reasoning, the extinguishing effect of retardants is higher than the effect able to suppress fire of $8.000 \mathrm{kWm}^{-1}$ intensity, typical of crown fire, but lower than fire intensity of $18.000 \mathrm{kWm}^{-1}$, which can be observed in extreme fires.

4. Aerial firefighting can be effective up to $3.400 \mathrm{kWm}^{-1}$ (Silva, 2002). In the comparison of effectiveness its value is 1 .

5. If the value of the effectiveness of water is 1 at $3.400 \mathrm{kWm}^{-1}$, the value of required effectiveness has to be 2.35 at $8.000 \mathrm{kWm}^{-1}$, and 5.3 at fire intensity of $18.000 \mathrm{kWm}^{-1}$.

Following from the above, the effectiveness factor of retardants can be considered , $4 \div 5$ ” expressed in water equivalent, based on expert estimation. It implies that it can suppress a quite fierce fire of intensity $13.600 \mathrm{kWm}^{-1}-17.000 \mathrm{kWm}^{-1}$, which is rather rare. This value takes into account the practical experience that retardants are not always able to provide effective protection against crown fires, though usually they are. For further calculations, the author has rounded the value of professional estimation up to 5 , and it will be used for calculations.

In the assessments of the effectiveness of extinguishers, the author has met the opinion several times that foams are 3 times, retardants are 9 times more effective than water (Theo, 2009; George, 2013). The series (water $=1$, foam $=3$, retardant $=9$ ) obviously reflects rather a logical relationship than actual 
effectiveness. The author seeks to determine the effectiveness of retardants with his own hypothesis analysis - because of differing values in his own tests with foams.

Based on the above, the author's hypothesis is that the effectiveness factor of retardants given by the distributor or producer companies reaches the value of 9 . It can be examined in several ways, aimed at the following: A) the amount of the extinguisher; B) the intensity of the fire; C) cost-effectiveness. Obviously, there would be a fourth method as well, when all the above are examined together, but it is justifies only in the case, when the hypothesis is affirmed in one of them at least.

A) The producer suggests that the amount of extinguisher needed in one unit of surface is the maximum amount remaining on the foliage in the case of retardants, too. So, we do not meet increased effectiveness in terms of quantity. The hypothesis cannot be justified in terms of quantity.

B) In terms of fire intensity, the effectiveness factor of 9 means that the same amount can suppress fire of intensity which is 9 times higher. It implies that retardants have to be able to suppress forest fires of $30.600 \mathrm{kWm}^{-1}$ intensity. However, practice does not consider such extreme fire intensity. In addition, as it was mentioned before, there is no guarantee that it can suppress fire of $18.000 \mathrm{kWm}^{-1}$ intensity, which happens quite frequently. The hypothesis cannot be justified in this case either.

C) The third way to examine the hypothesis requires a concrete efficiency analysis, which will be detailed below. The price of the retardants has to be at least twice of the price of the foam concentrate; it is not possible to find a product cheaper than $8 € \mathrm{~kg}^{-1}$. The mixing rate of retardants suggested by the producers and distributors is at least $25 \%$, so this percentage was considered in the calculations.

The value of the effectiveness coefficient is counted with 5, given this value by expert estimation, that is $Y_{R}=5$. It means, the effectiveness of the retardant is 2.5 higher than the effectiveness of foam. Using on-board installed tank in both cases, the losses are also the same. Example for the above:

$$
\begin{array}{ll}
\text { - } & C_{\text {ret }}=8 € \mathrm{~kg}^{-1} \\
\text { - } & R_{\text {mix }}=25 \% \\
\text { - } & C_{R}=0.3 € \mathrm{~kg}^{-1}+2 € \mathrm{~kg}^{-1}=2.3 € \mathrm{~kg}^{-1} \\
\text { - } & Y_{\mathrm{R}}=5 \\
\text { - } & \mathrm{C}_{\mathrm{R}=\mathrm{W}}=2.3 € \mathrm{~kg}^{-1} / 5=0.46 € \mathrm{~kg}^{-1} \\
\text { - } & \gamma_{\mathrm{T}}=0,9 \\
\text { - } & \mathrm{C}_{\mathrm{R}=\mathrm{W} \_ \text {eff }}=0.46 € \mathrm{~kg}^{-1} / 0,9=0.51 € \mathrm{~kg}^{-1}
\end{array}
$$

Based on the above, the conclusion should be that the efficiency of the retardant expressed by water equivalent is less than that of the water itself. This result obviously can't be logical if the practice uses retardants regularly as an effective extinguishing material. The solution is that the pure water itself is unable to suppress the fire above limited fire intensity $\left(3400 \mathrm{kWm}^{-1}\right)$, however the retardant is. Therefore, even if water is a cheaper solution in case of higher fire intensity its value is basically nothing. Although retardant seems to be irrationally expensive expressed by water equivalent but the capability extent to such a dimension, where water objectively can't be itself.

\section{References}

Fibla D.V.M. and Urbina, J.C.G.: Restardantes en la lucha contra incendios forestales; I. Symposium Internacional, La Gestión de los Medios Aéreos en la Defensa Contra los Incendios Forestales, Córdoba, Spain, 28-30 October, 2002

George, C.: ICL Biogema Sponsor presentation, Aerial Fire Fighting Conference, Aix-en-Provence, France 10-11, April, 2013

Gould, J., Plucinski, M., McCarthy, G., Hollis, J., Handmer, J. and Ganewatta, G.: Effectiveness and efficiency of aerial fire fighting in Australia; Fire Note; Issue 50, 2009 November, Fire Note is 
published jointly by the Bushfire Cooperative Research Centre (Bushfire CRC) and the Australasian Fire and Emergency Service Authorities Council (AFAC)

Imreh, L., Blaskovics, Zs. and Restas, A.: Új módszerek a légi tüzoltásban; Repüléstudományi Közlemények 2013. (2) HU ISSN 1789-770X, download: http://www.repulestudomany.hu/kulonszamok/2009_cikkek/Imreh_L-Blaskovits_Zs-Restas_A.pdf

Jambrik, R.: Légitámogatás nélkül nehéz, nagyon nehéz lett volna, Vedelem, ISSN: 1218-2958, 14 (6), pp. 51-52, 2007, download: http://www.vedelem.hu/letoltes/tanulmany/tan126.pdf

Restas, A.: R-20F Method: An approach for measuring the isolation effect of foams used fighting forest fires, ACADEMIC AND APPLIED RESEARCH IN MILITARY SCIENCE 11: (2) pp. 233247. 2012

Restas, A.: Suppression capability of foams used fighting against forest fires with the test of weight rate remained on the crown surface R-10A Method - weight effectiveness experiment; Manuscript, under publishing, $7^{\text {th }}$ ICFFR, Coimbra, Portugal, 2014

Silva, F. R.: Investigación y Capitalización de la Experiencia en el Empleo de Medios Aéros en la Defensa Contra los Incendios Forestales, La gestión de los Medios Aéros en la defensa conzta los incendios forestales, I. Simposium Internacional, Córdoba, Spain, 2002

Theo, M.T.: Initial Attack Air Tanker - Marsh S-2AT Turbo Tracker; Presentation, Aerial Fire Fighting Conference, Rome, Italy, 3-4 November, 2009 